\title{
The Current International Monetary System and Global Imbalances
}

\author{
Ren-Gui ZHANG ${ }^{1, a}$ and Hao-Wen FANG ${ }^{2, b, *}$ \\ ${ }^{1}$ School of Economics, Shenzhen Polytechnic, Shenzhen, China \\ ${ }^{2}$ School of Economics, Shenzhen Polytechnic, Shenzhen, China \\ azhangrg@szpt.edu.cn, bsysufanghw@126.com \\ ${ }^{*}$ Corresponding author
}

\begin{abstract}
Keywords: International monetary system, Reserve currency, Current account, Global imbalances
\end{abstract}
\begin{abstract}
This paper examines whether the international currency system has influenced global imbalances. We present an analytical framework concerning two sovereign currencies as a reserve currency system. We find that the current international monetary system is an important reason for global economic imbalances. Within the current international monetary system, it is difficult to solve the problem of reserve currency countries' current account deficits and global imbalances by adjusting the relative price, interest rates and exchange rates. Moreover, our model shows that the current account surplus of a reserve currency country could alleviate the current account deficit of the other one.
\end{abstract}

\section{Introduction}

Global imbalances, or more precisely, global current account imbalances, which refer to the large current account deficits and surpluses, have emerged in the world economy during the last 20 years. The imbalances have centered on the large current account deficits of the United States, which peaked at close to $6 \%$ of gross domestic product (GDP) in 2006, and the corresponding surpluses in the rest of the world, in particular developing Asia, Middle East, and Russia. The massive deficit in the U.S. trade and current accounts is one of the most striking features of the current global economy and one of the most worrying. Although the current account deficit finally began to shrink in 2011, it remained at more than 3 percent of GDP-more than $\$ 490$ billion.

Global imbalances have become a central question in international macroeconomics. Economists have given varieties of interpretations about global imbalances. One of influential researches can be traced back to Triffin's article in 1960, which discussed Gold- dollar standard Bretton Woods system defects. Based on the statistical analysis of U.S. balance of payments and gold reserves and other countries' dollar reserves, Triffin (1960) presented the famous "Triffin dilemma" -- If the U.S. meets the demand growth for the dollar, the dollar's foreign debt will exceed the U.S. gold reserves, which will eventually lead to a dollar crisis and the collapse of the Bretton Woods system; If U.S. refuses to meet the growth in demand for dollar reserves, the world will fall into international liquidity shortages. After the subprime mortgage crisis, domestic and foreign scholars further recognized the intrinsic defects of the existing international monetary system.

Kindleberger (1969) noted that reserves can be added only by new gold production, which is inadequate in some sense. Dooley et al. (2004) presented the views of Bretton Woods II (also known as DFG theory). It holds the opinion that the fixed exchange rate area of new peripheral Asian countries rebuilt the U.S-centred Bretton Woods II. Peripheral countries often adopt export-led economic growth strategies (undervalued exchange rates, capital controls and other policies) to achieve continued surplus over the centre. That is leading to global imbalances. McKinnon (2005, 2007) believed that as the current world is dollar denominated, so the United States may borrow foreign currency indefinitely to conceal its relatively low level of savings without having to "correct" the current account deficit. If the U.S. dollar is not an international reserve currency, the U.S. deficit 
cannot last more than 20 years. By analyzing the International Monetary evolution since 1915, Mundell (2007) indicated that global imbalances associated with the U.S. dollar is related to the rise of importance of the U.S. dollar in the international monetary system of the 20th century, and this imbalance will continue unless U.S. dollar's position as the only international currency is replaced. In June 2008 at the International Economic Association Meeting, Greenwald and Stiglitz (2008) pointed out that the crisis in Asia, Latin America and Eastern Europe as well as the long-term growth of the U.S. trade deficit (and the concomitant impact of deflation) is a long-term significant characteristic of the current international monetary system. Based on a simple portfolio balance model, Andreas (2014) showed theoretically that the global demand for reserve assets by central banks may lower the current account balance of the reserve-issuing country.

First, the traditional literature has pointed out that global imbalances are inevitable in the current international monetary system with only one current reserve. The diversification of reserves into various competing reserve currencies would alleviate their effects since they would be shared by various countries. Hence, this paper provides a model with two current reserve countries for this interpretation. According to the monetary approach (Johnson, 1972; Greenwald and Stiglitz, 2008), this paper establishes an analytical framework with two currency reserve countries. With the rise of the euro and RMB, the future pattern of the currency reserve system will change. That may be pushing the currency reserve system to diversify. Of cause, this model with one currency reserve is a special example of our model.

Second, in order to understand the global imbalances, we base our analysis on the literature on the determinants of the current account (Chinn and Prasad, 2003; Chinn et al., 2013; Gruber and Kamin, 2007; Greenwald and Stiglitz, 2008). These papers examine how private agents' decisions with regard to savings and investment give rise to private capital flows, which, in turn, shape current account balances. The literature usually finds that the main reserve currency country, the US, is an outlier, whose current account is persistently overpredicted. Using in-sample and out-of-sample predictions, Chinn and Ito (2007) concluded that the US current account is systematically overpredicted since the mid 1990s, a fact not observed for any other country. Balakrishnan et al. (2009) found a positive residual for the US signaling an unexplained preference for US assets. Our model takes into account trade surplus, capital flows, credit creation, economic growth, reserve currency demand factors.

Then, in our model, we find that the current international monetary system with single international reserve currency is an important reason for global economic imbalances. Within the Current International Monetary System, it is difficult to solve the problem of reserve currency countries' current account deficits and global imbalances by adjusting relative prices, interest rates and exchange rates. However, in the model of two international reserve currencies, when the U.S. deficit is too much, another reserve currency surplus country may increase its deficit, which will meet both the needs of non-reserve currency countries and reduce the U.S. deficit.

The rest of this paper is organized as follows. Section 2 presents a differential equation model about the reserve currency system. Section 3 presents three propositions and the solution of global economic imbalances. Section 4 is the conclusion.

\section{The Model}

\section{Several Important Equations}

To simplify the analysis, assume there are $n$ countries, and let's set country 1 and 2 as the currency reserve countries, and other ( $n-2)$ countries as the non-currency reserve country. Globally, at any time $t$, all the countries' net total exports should sum to zero and all the countries' net total capital inflows should sum to zero. So, we can get an important constraint equation:

$$
\sum_{k=1}^{n} N X_{k t}=N X_{1 t}+N X_{2 t}+\sum_{k=3}^{n} N X_{k t}=0
$$




$$
\begin{aligned}
& \sum_{k=1}^{n} N C F_{k t}=N C F_{1 t}+N C F_{2 t}+\sum_{k=3}^{n} N C F_{k t}=0 \\
& N X_{1 t}+N X_{2 t}+N C F_{1 T}+N C F_{2 T}=-\left(\sum_{k=3}^{n} N X_{k t}+\sum_{k=3}^{n} N C F_{k t}\right)
\end{aligned}
$$

where $N X_{\mathrm{kt}}, N C F_{k t}$ indicate country $k$ 's net exports and capital inflows respectively at time $t$.

Suppose when $t=0$, central bank's foreign reserve of country $k$ is $R_{k 0}$, among the increased foreign currency, $\theta_{k}$ is changed into central bank's foreign reserve, apparently $\theta_{k}$ value ranges $0<\theta_{k}<1$, then the central bank's foreign reserve of country $k$ at time $t$ should be :

$R_{k t}=R_{k 0}+\int_{0}^{t} \theta_{k} N X_{k t} d t+\int_{0}^{t} \theta_{k} N C F_{k t} d t$

Make $d R_{k t}$ represents $R_{k t}$ 's derivative against time, so the variable of central bank's foreign currency of country $k$ at time $t$ is:

$$
\frac{d R_{k t}}{d t}=\theta_{k} N X_{k t}+\theta_{k} N C F_{k t}
$$

\section{Money Market Equilibrium Equation}

As at any time ${ }^{t}$, country ${ }^{k}$ 's basic money supply ${ }^{M_{k t}}$ can be divided into two parts (Williamson, 1987): foreign reserve $R_{k t}$ and its central bank's credit creation $D_{k t}$, so the money supply equation of country ${ }^{k}$ at time ${ }^{t}$ should be:

$M_{k t}=D_{k t}+R_{k t}$

Substitute Eq. (4) into Eq. (6), the money supply equation of country $k$ at time $t$ should be:

$$
M_{k t}=R_{k 0}+\int_{0}^{t} \theta_{k} N X_{k t} d t+\int_{0}^{t} \theta_{k} N C F_{k t} d t+D_{k t}
$$

where $N X_{k t}$ and $N C F_{k t}$ meet Eq.(1) and Eq.(2). Money market equilibrium equation of country $k$ at time $t$ should be:

$$
M_{k t}=P_{k t} \times L_{k t}\left(Y_{k t}, i_{k t}\right)
$$

where $P_{k t}, Y_{k t}, i_{k t}$ indicate respectively the domestic price level, total production, interest rate of country $\mathrm{k}$ at time $\mathrm{t}, L_{k t}$, which is actual money demand in country $k$ at time $t$, is the function of $Y_{k t}$ and $i_{k t}$, and $\partial L_{k t} / \partial Y_{k t}>0, \partial L_{k t} / \partial i_{k t}<0$.

Substitute Eq. (7) into Eq. (8), money market equilibrium equation of country $k$ at time $t$ should be:

$$
R_{k 0}+\int_{0}^{t} \theta_{k} N X_{k t} d t+\int_{0}^{t} \theta_{k} N C F_{k t} d t+D_{k t}=P_{k t} \times L_{k t}\left(Y_{k t}, i_{k t}\right)
$$

To sum up, at phase $t$, with sovereign currency as international reserve, the global money market equilibrium equation should be:

$$
R_{1 t}+R_{2 t}+D_{2 t}+D_{2 t}+\sum_{k=3}^{n} R_{k t}+\sum_{k=3}^{n} D_{k t}=\sum_{k=1}^{2} P_{k t} \times L_{k t}\left(Y_{k t}, i_{k t}\right)+\sum_{k=3}^{n} P_{k t} \times L_{k t}\left(Y_{k t}, i_{k t}\right) \square(
$$

where $R_{k t}(k=\{1,2,3, \ldots n\})$ satisfies Eq. (4). 


\section{The International Monetary System}

\section{The Economical Growth}

Based upon the basic theory framework established in section two, this part will analyze whether current international monetary system is one of the important causes of global imbalances.

Get the derivative of $\mathrm{t}$ in Eq. (9), we get:

$\theta_{k} N X_{k t}+\theta_{k} N C F_{k t}=-\frac{d D_{k t}}{d t}+\left(\frac{d P_{k t}}{d t} L_{k t}\left(Y_{k t}, i_{k t}\right)+P_{k t}\left(\frac{\partial L_{k t}}{\partial t} \frac{d Y_{k t}}{d t}+\frac{\partial L_{k t}}{\partial t} \frac{d i_{k t}}{d t}\right)\right)(11)$

where $\frac{d P_{k t}}{d t}, \frac{\partial L_{k t}}{\partial Y_{k t}}, \frac{d Y_{k t}}{d t}, \frac{d D_{k t}}{d t}, \frac{\partial L_{k t}}{\partial i_{k t}}, \frac{d i_{k t}}{d t}$ denote respectively country $k$ 's variation ratio, currency demand changes caused by changes of production per unit, domestic production increase rate, central bank credit creation increase rate, currency demand changes and interest rate changes. From Eq. (5) we can infer the left part of Eq. (11) represents country $k$ 's central bank international reserve change at phase $t$, so we have:

$$
\frac{d R_{k t}}{d t}=-\frac{d D_{k t}}{d t}+\left[\frac{d P_{k t}}{d t} L_{k t}\left(Y_{k t}, i_{k t}\right)+P_{k t}\left(\frac{\partial L_{k t}}{\partial Y_{k t}} \frac{d Y_{k t}}{d t}+\frac{\partial L_{k t}}{\partial t} \frac{d i_{k t}}{d t}\right)\right]
$$

In Eq. (12), the first item on the right is country $k$ 's domestic demand for currency at phase $t$, the first item on the left is country $k$ 's credit creation at phase $t$. Eq. (12) shows that a country's demand for international reserve is in positive correlation with its currency demand caused by factors such as economical increase. However, it is in negative correlation with its domestic credit creation. Hence, we can get proposition 1. The proof of Eq. (14) is in Appendix A.

Proposition 1. If the price level and interest rate are relatively stable $\left(\frac{d P_{k t}}{d t}=0, \frac{d i_{k t}}{d t}=0\right)$, a country needs to continually increase its domestic credit creation or international reserve $\left(\frac{d D_{k t}}{d t}>0\right.$ or $\frac{d R_{k t}}{d t}>$ 0 ) to maintain or promote its economical growth $\left(\frac{d Y_{k t}}{d t}>0\right)$.

The significance of proposition 1 lies in that it reveals when the price level and interest rate are relatively stable, a country needs to increase its domestic credit creation or international reserve correspondingly to maintain its economical growth.

\section{The Constant Deficit}

Transpose and deform Eq. (12):

$$
N X_{k t}=\frac{1}{\theta_{k}}\left(\frac{d P_{k t}}{d t} L_{k t}\left(Y_{k t}, i_{k t}\right)+P_{k t}\left(\frac{\partial L_{k t}}{\partial t} \frac{d Y_{k t}}{d t}+\frac{\partial L_{k t}}{\partial t} \frac{d i_{k t}}{d t}\right)-\frac{d D_{k t}}{d t}\right)-N C F_{k t}
$$

Applying constraint identical Eqs. (1), (2) and (13), we have the following equation:

$$
N X_{1 t}+N X_{2 t}=-N C F_{1 t}-N C F_{2 t}-\sum_{k=3}^{n} \frac{1}{\theta_{k}}\left(-\frac{d D_{k t}}{d t}+\frac{d P_{k t}}{d t} L_{k t}\left(Y_{k t}, i_{k t}\right)+P_{k t}\left(\frac{\partial L_{k t}}{\partial t} \frac{d Y_{k t}}{d t}+\frac{\partial L_{k t}}{\partial t} \frac{d i_{k t}}{d t}\right)\right)
$$

The proof of Eq. (14) is in Appendix B. Eq. (14) shows that constant account deficits $\left(-N X_{1 t}-N X_{2 t}\right)$ of reserve currencies are in positive correlation with non-reserve currency countries' international reserve increase, but are in negative correlation with reserve currency countries' net capital inflows. From Eq. (14) we can further infer Proposition 2.

Proposition 2. Within the international monetary system with sovereign currency as international reserve currency, if reserve currency country's net capital outflow is insufficient to meet the demand increase for international reserve from non-reserve currency country, then reserve currency country will have constant deficit. It means that if 
$-N C F_{1 t}-N C F_{2 t}<\sum_{k=3}^{n} \frac{1}{\theta_{k}}\left(-\frac{d D_{k t}}{d t}+\frac{d P_{k t}}{d t} L_{k t}\left(Y_{k t}, i_{k t}\right)+P_{k t}\left(\frac{\partial L_{k t}}{\partial t} \times \frac{d Y_{k t}}{d t}+\frac{\partial L_{k t}}{\partial t} \times \frac{d i_{k t}}{d t}\right)\right)$

then, $N X_{1 t}+N X_{2 t}<0$.

\section{The International Balance Surplus}

By a similar argument, if reserve currency country's net capital outflow can meet the demand increase for international reserve from non-reserve currency country, we can discuss the international balance surplus.

Proposition 3. Within the international monetary system with sovereign currency as international reserve currency, if reserve currency country's net capital outflow can meet the demand increase for international reserve from non-reserve currency country, then reserve currency country can eliminate constant deficit or even have international balance surplus. It means that if

$-N C F_{1 t}-N C F_{2 t} \geq \sum_{k=3}^{n} \frac{1}{\theta_{k}}\left(-\frac{d D_{k t}}{d t}+\frac{d P_{k t}}{d t} L_{k t}\left(Y_{k t}, i_{k t}\right)+P_{k t}\left(\frac{\partial L_{k t}}{\partial t} \times \frac{d Y_{k t}}{d t}+\frac{\partial L_{k t}}{\partial t} \times \frac{d i_{k t}}{d t}\right)\right)$ then $N X_{1 t}+N X_{2 t} \geq 0$.

\section{The Solution of Global Imbalances}

Within the monetary system with a sovereign currency as an international reserve currency, is it likely to eliminate the reserve currency country's constant deficit through adjustment of relative prices, interest rates or exchange rates? Judging from Eq. (14), as long as the demand for the reserve currency keeps rising, it is unlikely to eliminate reserve currency country's trade deficit and global imbalances by adjusting the exchange rates of the reserve currency country against other countries. The non-reserve currency countries' international reserves total growing demand cannot be met by a net capital outflow of reserve currency countries, and no non-sovereign currency third parties would supply international reserves according to world demand. Then international reserves can only be supplied by reserve currency country through current account deficit, which led to reserve currency countries' current account deficit and global imbalances. And, as long as the total demand for international reserves is growing, any efforts to solve the long-term trade deficit of reserve currency countries and global imbalances through exchange rate policy are invalid. Moreover, the historical experience has shown that after "Plaza Accord" in 1985, the dollar devaluation did not solve the fundamental problem of the U.S. trade deficit.

Thus, the severe imbalances of current global economy, characterized by U.S. massive trade deficit and external debt versus China and other emerging market countries' large trade surpluses and high foreign exchange reserves, may be largely due to the current international monetary system's "rules of the game"-- using a sovereign currency as the international reserve currency and the U.S. dollar's reserve currency status.

How to solve the problem of global imbalances? Based on our two reserve currency models, Eq. (14) shows that constant account deficits of reserve currencies are composed of two terms: $-N X_{1 t}$ and $-N X_{2 t}$. Hence, we find that when the U.S. deficit is too much, another reserve currency surplus country may increase its deficit, which will meet both the needs of non-reserve currency countries and reduce the U.S. deficit. It means that the diversification of reserves into various competing reserve currencies would alleviate their effects since they would be shared by various countries. Thus, seeking another international reserve currency in accordance with the world's demand is particularly important.

\section{Conclusion}

Global imbalances have become a central question in international macroeconomics. Economists have given varieties of interpretations about global imbalances. This paper complements these literatures by showing the model with two international reserve currencies. The current global 
imbalances, to a large extent, stem from the current international monetary system using sovereign currency "the dollar" as international reserve currency. It is unfair to attribute the root of global imbalances to China's manipulation of exchange rates. It is unrealistic to seek to eliminate America's constant trade deficit and global imbalances by RMB appreciation. To solve the problem of global imbalances, seeking another international reserve currency is of utmost importance.

Our findings could raise a number of interesting issues for future research. For instance, nowadays, $\mathrm{RMB}$ is popular in Asia, and is regarded as another international reserve currency. It means that in Asia, the international reserve currency system is in accord with our model. In order to solve Global imbalances, it would be interested in the empirical study in Asia.

\section{Acknowledgements}

This work was supported by the "13th Five-year" planning project of Shenzhen Philosophy and Social Science (Item No. 135C005) and the "12th Five-Year" plan of the philosophy and social sciences of Guangdong Province co-construction project(Item No. GD15XLJ03).

\section{Appendix A. Proof of Proposition 1}

Suppose that the price level and interest rate are relatively stable $\left(\frac{d P_{k t}}{d t}=0, \frac{d i_{k t}}{d t}=0\right)$. Substitute these equations into Eq. 12, we have

$\frac{d R_{k t}}{d t}=-\frac{d D_{k t}}{d t}+P_{k t} \frac{\partial L_{k t}}{\partial Y_{k t}} \frac{d Y_{k t}}{d t}$

That is

$P_{k t} \frac{d Y_{k t}}{d t} \frac{\partial L_{k t}}{\partial Y_{k t}}=\frac{d R_{k t}}{d t}+\frac{d D_{k t}}{d t}=\frac{d M_{k t}}{d t}$

As we know $\frac{\partial L_{k t}}{\partial Y_{k t}}>0$, then $\frac{d R_{k t}}{d t}+\frac{d D_{k t}}{d t}>0$, or $\frac{d M_{k t}}{d t}>0$, will result in $\frac{d Y_{k t}}{d t}>0$.

\section{Appendix B. Proof of Eq. (14)}

Applying constraint identical Eq. (1), (2) and (13), then:

$$
\begin{aligned}
& N X_{1 t}+N X_{2 t}=-\sum_{k=3}^{n} N X_{k t}=\sum_{k=3}^{n} N C F_{k t}-\sum_{k=3}^{n} \frac{1}{\theta_{k}}\left(-\frac{d D_{k t}}{d t}+\frac{d P_{k t}}{d t} L_{k t}\left(Y_{k t}, i_{k t}\right)+P_{k t}\left(\frac{\partial L_{k t}}{\partial t} \times \frac{d Y_{k t}}{d t}+\frac{\partial L_{k t}}{\partial t} \times \frac{d i_{k t}}{d t}\right)\right) \\
& =-N C F_{1 t}-N C F_{2 t}-\sum_{k=3}^{n} \frac{1}{\theta_{k}}\left(-\frac{d D_{k t}}{d t}+\frac{d P_{k t}}{d t} L_{k t}\left(Y_{k t}, i_{k t}\right)+P_{k t}\left(\frac{\partial L_{k t}}{\partial t} \times \frac{d Y_{k t}}{d t}+\frac{\partial L_{k t}}{\partial t} \times \frac{d i_{k t}}{d t}\right)\right)
\end{aligned}
$$

\section{References}

[1] Andreas, S., 2014. Current account balance and dollar standard: Exploring the linkages. Journal of International Money and Finance 41, 65-94.

[2] Balakrishnan, Ravi, Bayoumi, Tamim, Tulin, Volodymyr, 2009. Rhyme or reason: what explains the easy financing of the U.S. current account deficit? IMF Staff Pap. 56 (2), 410-445.

[3] Chinn, Menzie D., Eichengreen, Barry, Ito, Hiro, 2013. A forensic analysis of global imbalances. Oxford Econ. Pap. (forthcoming).

[4] Chinn, Menzie D., Ito, Hiro, 2007. Current account balances, financial development and institutions: assaying the world ”saving glut”. J. Int. Money Finance 26, 546-569.

[5] Chinn, Menzie D., Prasad, Eswar S., 2003. Medium-term determinants of current accounts in industrial and developing countries: an empirical exploration. J. Int. Econ. 59, 47-76. 
[6]Dooley, M.P., David, F.L., and Garber, P., 2004. The Revived Bretton Woods System. International Journal of Finance \& Economics, 9(4), 307-313.

[7]Greenwald, B., and Stiglitz, J., 2008. A Modest Proposal for International Monetary Reform. International Economic Association Meeting, Istanbul, June, 2008.

[9]Gruber, JosephW., Kamin, Steven B., 2007. Explaining the global pattern of current account imbalances. J. Int. Money Finance 26, 500-522.

[10]Johnson, H.G., 1972. The Monetary Approach to Balance-of-Payments Theory. Journal of Financial and Quantitative Analysis, 7(2), 1555 -1572.

[11]Kindleberger, Charles P., 1969. Europe and the Dollar. MIT Press, Cambridge, Mass.

[12]McKinnon, R.I., 2005. Trapped by the International Dollar Standard. Journal of Policy Modeling, 27( 4), 477-485.

[13]McKinnon, R.I., 2007. The Transfer Problem in Reducing the U. S. Current Account Deficit. Journal of Policy Modeling, 29(5), 669-675.

[14]Mundell, R., 2007. Dollar Standards in the Dollar Era. Journal of Policy Modeling, 29(5), 676-690.

[15]Triffin, R., 1960. Gold and the Dollar Crisis. Yale University Press, New Haven.

Williamson, J., 1987. The Open Economy and the World Economy, Basic Books, New York. 